ISSN 0258-7122

Bangladesh J. Agril. Res. 34(3) : 351-359, September 2009

\title{
VARIATION OF GRAIN GROWTH OF WHEAT CULTIVARS
}

\author{
S.K. ADHIKARY, M.Z. ALAM AND N.K. PAUL
}

\begin{abstract}
An experiment was carried out to study the grain growth pattern of wheat (Triticum aestivum L.) cultivars and to find out association and linear regression of spike weight and grain weight with time. Spike characters indicated that cultivar differences were significant in all the cases with a few exceptions. Linear regression and correlation coefficients revealed that the association between both spike weight and grain weight with time were highly positively significant among the cultivars but their regression coefficients were nonsignificant.
\end{abstract}

Key Words: Grain growth, correlation, regression, wheat.

\section{Introduction}

Genetic potentialities and environment including cultural practices determine yield, but final grain yield is mainly depended on potential grain growth of any cultivar. Number of grains/spike and grain size had provided much information about the structure of cereal crops, but little about the fundamental causes of variation in yield (Thorne, 1974). Seed weight/spike is dependent on the number of seeds and seed size and shape (Amin et al., 1995). The yield of a grain crop is a function of the rate and duration of accumulation of dry weight in the seed fraction and consequently factors influencing either the rate or duration will have a direct influence on yield. Gallaghar et al. (1976) established the usefulness of relating grain growth of wheat as a linear process and expressing final weight/grain as a product of a growth rate and duration. They commented that if cereals are to yield well in regions where drought and high temperature during grain filling are frequent, varieties must be bred which not only increase the rate but also sustain the duration of grain growth. Rawson and Evans (1970), Bremer (1972) and Rawson and Rawali (1972a) reported the differences in weight between grains within the year and the general pattern of such variation and its development with time. Bhardwaj and Verma (1985) observed that grain weight/ear and spikelet as well as single grain weight of wheat increased steadily from anthesis to maturity. Relative growth rate of grain showed differences in respect of the variety as well as the age of the grain. Knowledge in this regard is very scanty in wheat of Bangladesh. So, the present experiment was set up to find out variability of different phases of grain growth of wheat (Triticum aestivum L.) cultivars in the northern region of Bangladesh.

Department of Botany, University of Rajshahi, Rajshahi-6205, Bangladesh. 


\section{Materials and Method}

The experiment was conducted in the research field of the Department of Botany, University of Rajshahi, Bangladesh. Eight cultivars of wheat (Opata, BL 1183, C 306, BAW 452, BAW 171, Pavon 76, Kanchan and Barkat) were grown in a randomized complete block design with three replications. Each replication plot was $8 \mathrm{~m}$ long and $8 \mathrm{~m}$ wide. The field was prepared after repeated ploughings. Before sowing, basal doses of nitrogen (80 kg N/ha), TSP (40 kg $\left.\mathrm{P}_{2} \mathrm{O}_{5} / \mathrm{ha}\right)$ and MP (40 kg K $2 \mathrm{O} / \mathrm{ha}$ ) were added and were mixed with the soil. The seeds were sown on 10 November 2003 at the rate of $50 \mathrm{~kg} / \mathrm{ha}$. The row to row and plant to plant distances were $20 \mathrm{~cm}$ and $10 \mathrm{~cm}$, respectively. Spikes were harvested from the experimental field on 10 January 2004 onward. Before harvest, some spikes were tagged at different days of anthesis for each cultivar and harvests were taken at an interval of 7 days. Six harvests were taken during the period of experimentation. Six spikes of main tillers were cut (per replication $=2$ spikes) per cultivar at each harvest and they were dried in an oven at $85^{\circ} \mathrm{C}$ for 24 hours. After drying, the following characters were recorded: Spike weight, number of spikelets/spike, number of grains and grain weight. Statistical analysis was done accordingly for almost all the characters by a statistical package named Irristat Version 3.1 to show the significant difference among means. Linear regression analysis was carried out according to Gomez and Gomez (1984) with the help of Microsoft Excel data analysis tool pack.

\section{Results and Discussion}

The result of the present investigation indicates that cultivar differences were significant in all the cases except spike weight per main tiller at 21 days after anthesis (DAA). Rahman (2004) observed significant varietal difference of seed growth parameters in wheat at different DAA. Mean performance (Table 1) revealed that spike weight per main tiller and grain weight per spike increased gradually with time and showed variability in some cases. On the other hand, number of spikelets per spike and grain number per spike showed less variation in all the cases. Barkat showed the maximum mean values for all these parameters. The minimum values of spike weight per main tiller, number of spikelets per spike, number of grains per spike and grain weight per spike were obtained in Pavon 76, BL 1183, BAW 171 and C 306, respectively. Saha and Abi-Antaun (1988) reported that head weight per plant, grain number, grain size, and fertility are the most important yield contributing characters. Geweifel (1991) reported that variation in grain yield was most closely associated with variation in number of grains per spike and number of spikes per $\mathrm{m}^{2}$. Bouzerzour and Benmahamed (1991) observed a positive and highly significant correlation between grains per $\mathrm{m}^{2}$ and grains per spike and also between these components and yield. Rahman and Paul (1998) observed that spike weight increased with increasing time under irrigated condition, but decreased by water deficiency in 
Table 1. Mean values of spike characters at different days after anthesis of eight cultivars of wheat. Rajshahi, 2003.

Days after anthesis

\begin{tabular}{|c|c|c|c|c|c|c|c|c|}
\hline \multirow[t]{2}{*}{ Cultivars } & \multicolumn{2}{|c|}{7} & \multicolumn{2}{|c|}{14} & \multicolumn{4}{|c|}{21} \\
\hline & $\begin{array}{c}\text { Spike } \\
\text { weight(g) } \\
\text { / main } \\
\text { tiller }\end{array}$ & $\begin{array}{c}\text { No. of } \\
\text { spikelets/ } \\
\text { spike }\end{array}$ & \begin{tabular}{|c|} 
Spike \\
weight(g) \\
/ main \\
tiller \\
\end{tabular} & \begin{tabular}{|c} 
No. of \\
spikelets \\
spike1
\end{tabular} & \begin{tabular}{|c|} 
Spike \\
weight(g) \\
/ main \\
tiller \\
\end{tabular} & \begin{tabular}{|c|} 
No. of \\
spikelets/ \\
spike
\end{tabular} & $\begin{array}{c}\text { Grain } \\
\text { no./ } \\
\text { spike }\end{array}$ & $\begin{array}{c}\text { Grain } \\
\text { weight(g)/ } \\
\text { spike }\end{array}$ \\
\hline Opata & $0.53 \mathrm{bc}$ & $17.33 a$ & 0.69cd & $16.00 \mathrm{~b}$ & $1.27 \mathrm{a}$ & $17.33 a$ & 41.83ab & $0.84 c$ \\
\hline BL1183 & $0.64 \mathrm{ab}$ & 13.33c & $1.09 \mathrm{~b}$ & 13.67c & $1.55 a$ & 15.33b & 35.83b & $1.08 \mathrm{~b}$ \\
\hline C306 & $0.49 b c$ & $12.83 c$ & $0.56 \mathrm{~d}$ & $12.50 \mathrm{~d}$ & $1.27 \mathrm{a}$ & 16.83ab & $37.00 \mathrm{~b}$ & $0.42 \mathrm{e}$ \\
\hline Kanchan & $0.6 \mathrm{Iab}$ & $15.67 b$ & $0.81 \mathrm{c}$ & 17.17a & $1.52 \mathrm{a}$ & $17.67 \mathrm{a}$ & 41.00ab & $1.02 \mathrm{bc}$ \\
\hline BAW452 & $0.85 a$ & 16.50ab & l.18ab & $16.00 \mathrm{~b}$ & $1.70 \mathrm{a}$ & $17.00 \mathrm{a}$ & $46.50 \mathrm{a}$ & $1.30 \mathrm{a}$ \\
\hline BAWI7I & $0.50 \mathrm{bc}$ & 17.67a & $0.84 \mathrm{c}$ & $15.83 b$ & $1.13 a$ & $15.83 \mathrm{~b}$ & 27.67c & $0.63 d$ \\
\hline Pavon 76 & $0.46 b c$ & 16.33ab & $0.79 c$ & 16.33ab & $1.40 \mathrm{a}$ & 17.17a & 43.67ab & 0.83cd \\
\hline Barkat & $0.93 a$ & 17.33a & $1.27 \mathrm{a}$ & 16.33ab & $1.59 \mathrm{a}$ & $15.33 b$ & 41.00ab & $0.99 b c$ \\
\hline LSD at5\% & 0.25 & 1.75 & 0.16 & 1.07 & - & 1.27 & 8.49 & 0.21 \\
\hline \multicolumn{9}{|c|}{ Days after anthesis } \\
\hline \multirow[t]{2}{*}{ Cultivars } & \multicolumn{4}{|c|}{28} & \multicolumn{4}{|c|}{35} \\
\hline & $\begin{array}{c}\text { Spike } \\
\text { weight(g) } \\
\text { / main } \\
\text { tiller }\end{array}$ & \begin{tabular}{|c} 
No. of \\
spikelets/ \\
spike
\end{tabular} & \begin{tabular}{|c|} 
Spike \\
weight(g) \\
/ main \\
tiller \\
\end{tabular} & \begin{tabular}{|c} 
No. of \\
spikelets/ \\
spike
\end{tabular} & \begin{tabular}{|c|} 
Spike \\
weight(g) \\
/ main \\
tiller \\
\end{tabular} & \begin{tabular}{|c|} 
No. of \\
spikelets/ \\
spike
\end{tabular} & $\begin{array}{c}\text { Grain } \\
\text { no./ } \\
\text { spike }\end{array}$ & $\begin{array}{c}\text { Grain } \\
\text { weight(g)/ } \\
\text { spike }\end{array}$ \\
\hline Opata & $1.98 \mathrm{bc}$ & 1817a & $47.00 \mathrm{a}$ & 1.39bc & $1.88 \mathrm{~b}$ & 16.67bc & 43.67b & 1.33b \\
\hline BL1183 & $2.14 b$ & $15.17 b$ & 39.00ab & $1.62 b$ & $2.39 b$ & 13.17d & 32.17cd & $1.79 b$ \\
\hline C306 & $1.21 \mathrm{~d}$ & $14.50 \mathrm{~b}$ & 36.67b & 0.64ab & $2.20 \mathrm{~b}$ & 17.50b & 44.67b & $1.57 \mathrm{~b}$ \\
\hline Kanchan & $2.13 \mathrm{~b}$ & $17.50 \mathrm{a}$ & 38.00ab & $1.57 \mathrm{~b}$ & $2.33 \mathrm{~b}$ & 17.00b & $35.17 \mathrm{c}$ & $1.73 b$ \\
\hline BAW452 & $2.61 \mathrm{a}$ & 18.33a & 47.00a & $1.94 \mathrm{a}$ & $2.07 \mathrm{~b}$ & $16.00 \mathrm{bc}$ & 32.67cd & $1.56 \mathrm{~b}$ \\
\hline BAWI7I & $1.84 b c$ & 18.17a & 30.67b & $1.24 \mathrm{~cd}$ & $1.97 \mathrm{~b}$ & 17.00b & 26.67d & $1.44 \mathrm{~b}$ \\
\hline Pavon 76 & $1.49 \mathrm{~d}$ & 17.50a & 39.00ab & $1.05 \mathrm{~d}$ & $1.88 \mathrm{~b}$ & 17.00b & $36.50 c$ & 1,39b \\
\hline Barkat & $2.42 \mathrm{ab}$ & 17.00ab & 44.83a & 1.76ab & 3.53a & 19.33a & 60.33a & $2.85 a$ \\
\hline LSD at5\% & 0.35 & 2.48 & 9.31 & 0.31 & 0.66 & 1.68 & 6.17 & 0.50 \\
\hline & & & & s after al & sis & & & \\
\hline Cultivar & & & & & 42 & & & \\
\hline & $\begin{array}{r}\mathrm{S} \\
\text { wei } \\
/ \\
\mathrm{t}\end{array}$ & $\begin{array}{l}\text { pike } \\
\text { ight(g) } \\
\text { main } \\
\text { iller }\end{array}$ & $\begin{array}{r}\text { No. } \\
\text { spike } \\
\text { spi }\end{array}$ & $\begin{array}{l}\text { of } \\
\text { lets/ } \\
\text { ke }\end{array}$ & $\begin{array}{r}\text { Grain } \\
\text { spi }\end{array}$ & $\begin{array}{l}\text { no./ } \\
\text { ike }\end{array}$ & & $\begin{array}{l}\text { rain } \\
\text { sht(g)/ } \\
\text { oike }\end{array}$ \\
\hline Opata & 2.00de & & 16.67b & & 44.50ab & & $1.47 \mathrm{c}$ & \\
\hline BLI 183 & $2.68 \mathrm{~b}$ & & $13.83 c$ & & 37.67b & & 2.2lab & \\
\hline C306 & $2.57 \mathrm{bc}$ & & 16.17b & & 44.83ab & & 1.92b & \\
\hline Kanchan & $2.42 \mathrm{c}$ & & 17.67ab & & $38.00 \mathrm{~b}$ & & $1.78 b c$ & \\
\hline BAW452 & 2.98ab & & 16.67b & & 46.17a & & $2.30 \mathrm{a}$ & \\
\hline BAWI7I & $2.35 \mathrm{~cd}$ & & $18.00 \mathrm{a}$ & & 35.33b & & $1.76 \mathrm{bc}$ & \\
\hline Pavon76 & $1.80 \mathrm{e}$ & & 18.83a & & 37.17b & & $1.34 \mathrm{c}$ & \\
\hline Barkat & $3.22 \mathrm{a}$ & & 18.33a & & $52.00 \mathrm{a}$ & & $2.57 \mathrm{a}$ & \\
\hline LSD at $5 \%$ & 0.40 & & 1.35 & & 8.53 & & 0.44 & \\
\hline
\end{tabular}

In a colum, means followed by a common letter are not significantly different at $5 \%$ level by DMRT. 
the soil. Evans and Wardlaw (1976) observed that number of grains that develop in a spike of wheat is dependent on the number of florets and the effective fertilization of them after anthesis. Again, grain weight per ear is dependent on the number of grains and its size and shape (Amin et al., 1995).

Grain number per spikelet was considered as the main yield component in wheat by Hsu and Walton (1971). Bhuiya and Kamal (1994) stated that grain yield of wheat is the product of four components viz., number of ears per plant, number of spikelets per ear, number of grains per spikelet and individual grain weight. Some workers reported that the yield advantage of wheat mostly depends on the higher number of grains per unit area (Gale, 1979 and Perry and D'Antuono, 1989). Furthermore, the increased grain number has been arisen by spikes per unit area (Lupton, 1974) or more grains per spike (Syme, 1970) due to a higher spikelet number (Rawson, 1970) or a higher floret fertility (Angus and Sage, 1980). Rawson and Ruwali (1972b) suggested that high yields with uniform grain can be obtained by increasing spikelet number using branched ears, rather than by increasing seed set per spikelet.

Linear regression and correlation coefficients between spike weight on time and grain weight on time for the cultivars were studied and the results (Fig. 1) revealed that in all the cases, association between spike weight and time showed highly significant positive correlations which were $r^{2}=0.877 * *$ in Opata, $r^{2}=$ $0.984 * *$ in BL 1183, $\mathrm{r}^{2}=0.926 * *$ in C 306, $\mathrm{r}^{2}=0.935^{* *}$ in Kanchan, $\mathrm{r}^{2}=0.861 * *$ in BAW 452, $\mathrm{r}^{2}=0.976 * *$ in BAW 171, $\mathrm{r}^{2}=0.905$ in Pavon 76 and $\mathrm{r}^{2}=0.911^{* *}$ in Barkat but their corresponding regression coefficients were non-significant. Simpson (1968) observed very high positive correlation between weight of grain per plant and number of kernels per plant in wheat. Kulik (1985) observed that grain yield was positively correlated with number of ears per $\mathrm{m}^{2}$, number of productive tillers per $\mathrm{m}^{2}$ and number and weight of grains per main ear.

Figure 2 indicates that among the cultivars, the association between grain weight on time also showed highly positive correlations, such as $r^{2}=0.691^{* *}$ in Opata, $\mathrm{r}^{2}=0.965^{* *}$ in BL $1183, \mathrm{r}^{2}=0.944^{* *}$ in C $306, \mathrm{r}^{2}=0.818^{* *}$ in Kanchan, $\mathrm{r}^{2}=0.597^{* *}$ in BAW 452, $\mathrm{r}^{2}=0.948^{* *}$ in BAW 171, $\mathrm{r}^{2}=0.848^{* *}$ in Pavon 76 and $\mathrm{r}^{2}=0.802 * *$ in Barkat. On the other hand, their corresponding regression coefficients were also non-significant in all the cases. Briggs and Aytenfisu (1980) observed that kernels per ear and 1000-kernel weight was the most stable association of yield components in spring wheat. Islam (1977) found a significant positive correlation between grain yield per plant and 1000-seed weight. Labuschagne and Van-Deventer (1992) reported that grain number and grain weight of both primary and secondary tillers were significantly correlated with 


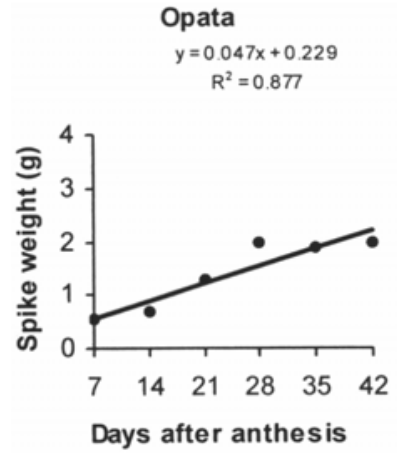

C 306

$y=0.062 x-0.43$

$R^{2}=0.926$

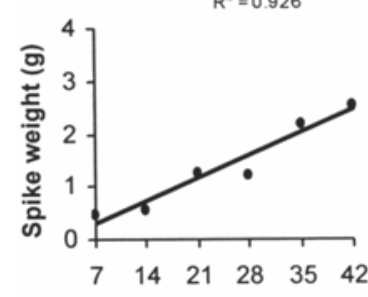

Days after anthes is

BAW 452

$y=0.058 x+0.475$

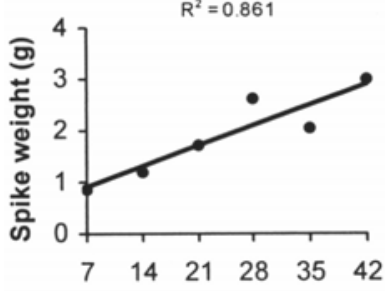

Days after anthesis

Pavon 76

$y=0.04 x+0.297$

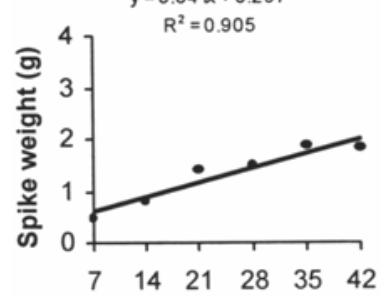

Days after anthes is
BL 1183

$y=0.060 x+0.279$

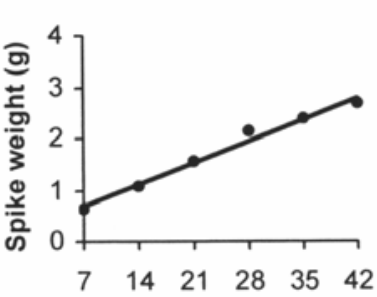

Days after anthesis

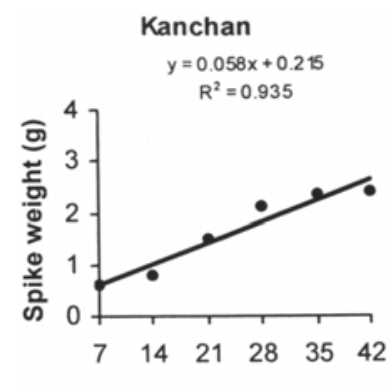

Days after anthes is

BAW 171

$y=0.054 x+0.03$

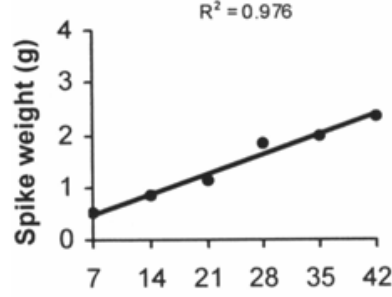

Days after anthesis

Barkat

$y=0.078 x+0.254$

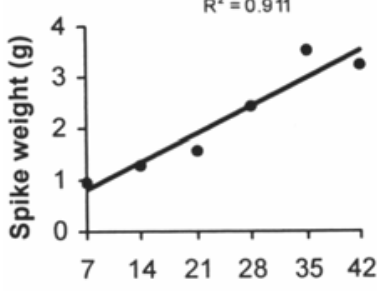

Days after anthesis

Fig. 1. Regression of spike weight on times (different days after anthesis) of eight cultivars of wheat. 


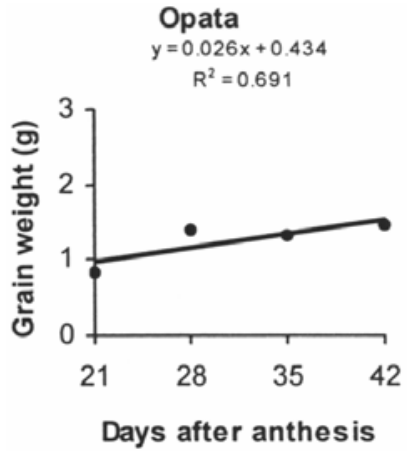

\section{306}

$y=0.078 x-1306$

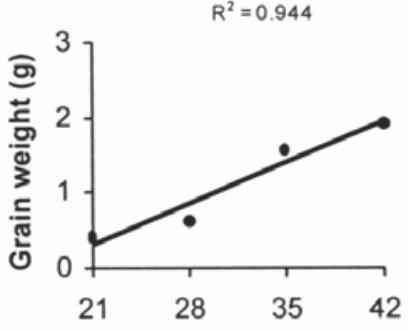

Days after anthes is

\section{BAW 452}

$y=0.037 x+0.596$

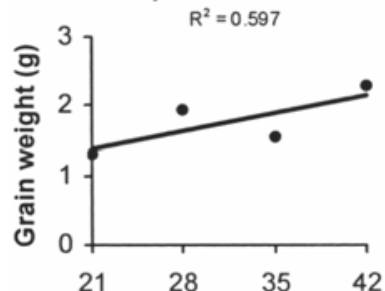

Days after anthes is

Pavon 76

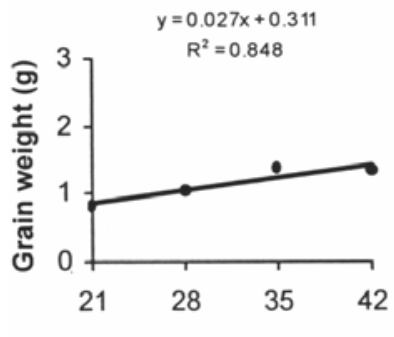

Days after anthes is

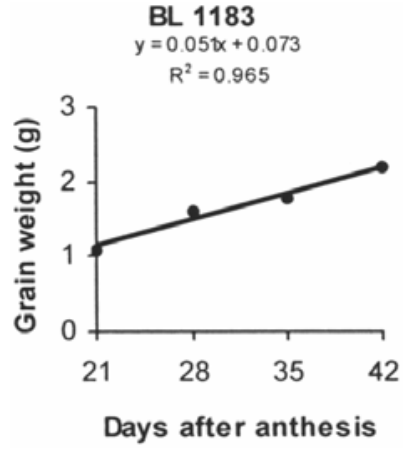

Kanchan

$y=0.035 x+0.427$

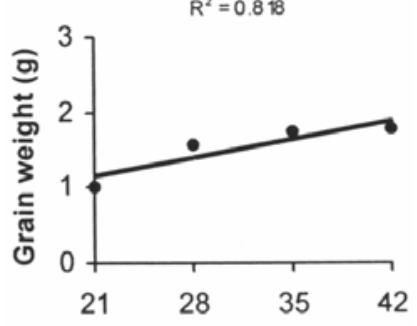

Days after anthesis

BAW 171

$y=0.05 x x-0.348$

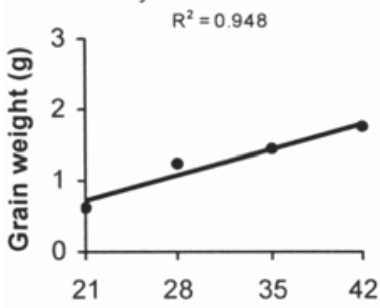

Days after anthesis

Barkat

$y=0.083 x-0.581$

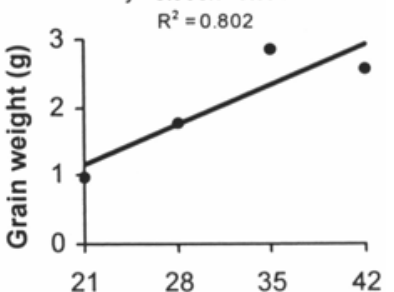

Days after anthes is

Fig. 2. Regression of grain weight on times (different days after anthesis) of eight cultivars of wheat. 
yield at two different moisture levels (80 and 50\% field capacity). Chai et al. (1993) noticed that grain weight per plant was correlated highly and significantly with dry weight per plant in wheat.

In the present investigation, it is observed that spike weight and grain weight had close relation with time. Therefore, independent and dependent variables were closely related each other and changed with time. Among the cultivars, wide variation was observed for all the spike characters at different days after anthesis.

\section{References}

Amin, M. R., M. Bodruzzaman., A. Shaheed and M. A. Razzaque. 1995. Effect of size of wheat seed on yield. Bangladesh J. Agril. Sci. 22: 347-349.

Bhardwaj, S. N. And V. Verma. 1985. Grain number and size as determinants of yield in wheat. Indian J. Agric. Sc. 55: 622-627.

Bhuiya, M. S. U. and A.M.A. Kamal. 1994. Developmental stages and grain yield components of wheat. Bangladesh J. Agril. Sci. 21: 335-341.

Bouzerzour, M. and A. Benmahamed. 1991. Correlation and regression studies of barley in eastern Algeria. RACHIS 10: 35-36.

Bremer, P. M. 1972. The accumulation of dry matter and nitrogen by grains in different positions of wheat ear as influenced by shading and defoliation. Aust. $J$. Biol. Sci. 25: 657-668.

Briggs, K. G. and A. Aytenfisu. 1980. Relationship between morphological characters above the flag-leaf node and grain yield in spring wheat. Crop Sci. 20: 350-354.

Chai, S. X., D.X. Wang and S. C. Chai. 1993. The use value of some characters concerning drought resistance in winter wheat under water stress. Acta Agriculturae Boreali Sinica 8(1): 1-6.

Evans, L. T. and 1. F. Wardlaw. 1976. Aspects of comparative physiology of grain yield in cereals. Adv. Agron. 28: 30 1-359.

Gale, M. D. 1979. The effects of the Norin-lO dwarfing genes on wheat. In: Proceedings of the 5th International Wheat Genetics Symposium. Held at New Delhi. pp. 978-987.

Gallagher, J. N., P. V. Biscoe and B. Hunter. 1976. Effects of drought on grain growth of wheat. Nature 264: 54 1-542.

Geweifel, H. G. M. 1991. Effect of N, P and K fertilization on grain yield and quality of barley under sandy soil conditions. Egyptian J. Agron. 16: 137-158. 
Gomez, K. A. and A. A. Gomez. 1984. Statistical procedure for agricultural research. John Wiley and Sons. New York.

Hsu, P. and P. D. Walton. 1971. Relationships between yields and its components and its structure above the flag leaf node in spring wheat. Crop Sci. 11: 190193.

Islam, M. A. 1977. Variation and association of yield components of wheat. Bangladesh J. Agric. 2: 233-238.

Kulik, D. 1985. Relation between yield formation in spring barley cv. Opal and preceding crops and fertilizer application. Rostlinna Vyroba. 31: 12331240.

Labuschagne, M. T. and C.S. Van-Deventer. 1992. The effect of moisture stress on the yield and yield components of several wheat cultivars and their F1 hybrids. J. Agron.\& Crop Sci. 168(3): 153-158.

Lupton, F. G. H. 1974. Root and shoot growth of semi-dwarf and taller winter wheats. Ann. Appl. Biol. 77: 129-144.

Perry, M. W. and M. F. D'Antuono. 1989. Yield improvement and characteristics of some Aust. spring wheat cultivars between 1860 and 1982. Aust. J. Agric. Res. 40: $457-472$.

Rahman, A. 2004. Effects of irrigation and nitrogen application on seed growth and yield of wheat. Bangladesh J. Seed Sci. \& Tech. 8: 63-71.

Rahman, M. S. and N. K. Paul. 1998. Effect of soil moisture regimes on physiological characters and yield of wheat cultivars. J. Bio-sci. 6: 5-10.

Rawson, H. M. 1970. Spikelet number, its control and relation to yield per ear in wheat. Aust. J. Biol. Sci. 23: 1-15.

Rawson, H. M. And K. N. Rawali. 1972a. Ear branching as a means of increasing grain uniformity in wheat. Aust. J. Agric. Res. 23: 55 1-559.

Rawson, I-I. M. and K. N. Ruwali. 1972b. Branched ears in wheat and yield determination. Aust. J. Agric. Res. 23: 54 1-549.

Rawson, H. M. and L. T. Evans. 1970. The pattern of grain growth within the ear of wheat. Aust. J. Biol. Sci. 23: 753-764.

Saha, H. K. and M. Abi- Antaun. 1988. Interrelationship between yield and yield component characters in Triticale. Bangladesh J. Agril. Sc. 15: 205-2 10.

Simpson, G. M. 1968. Association between grain yield per plant and photosynthetic area above the flag-leaf node in wheat. Can. J. Plant Sci. 48: 253-259. 
Syme, J. R. 1970. A high yielding Mexican semi-dwarf wheat and the relationship of yield to harvest index and other varietal characteristics. Aust. J. Exp. Agric. Anim. Husb. 10: 350-356.

Thorne, G. N. 1974. Physiology of grain yield of wheat and barley. Rep. Rothamsted Exp. Stn. Part 2: 5-25 